\title{
Pengaruh Serat Baja Canai Dingin Bergelombang Terhadap Kekuatan Tekan Dan Lentur Beton
}

\author{
Eka Faisal Nurhidayatullah \\ Program Studi Teknik Sipil, Fakultas Sains dan Teknologi, Universitas Teknologi Yogyakarta
}

\begin{abstract}
Abstrak
Beton merupakan material konstruksi yang bersifat getas. Kombinasinya dengan baja pada material beton bertulang menjadikan material beton yang getas getas menjadi daktail. Pada beton bertulang, beton bekerja menahan tekan sedangkan baja melawan tarik. Beton hanya bekerja pada serat tekan saja sedangkan selebihnya tidak berfungsi. Kelemahan beton tersebut mengakibatkan struktur beton bertulang mengalami retak lentur. Hal ini dikhawatirkan berpotensi menurunkan ketahanan strukturalnya. Untuk meminimalisir terjadinya retak maka kekuatan lentur (flexural strength) beton perlu ditingkatkan. Salah satu caranya yaitu dengan menambahkan bahan serat berkekuatan tarik tinggi ke dalam beton. Penelitian dilakukan dengan menggunakan serat baja canai dingin bergelombang sebagai bahan tambah pada beton. Dengan menambahkan material baja canai dingin yang dibuat berbentuk gelombang mampu meningkatkan kuat lentur dan ikatan beton. Pembuatan benda uji yang dilakukan yaitu beton normal, beton serat 1, 2, 3, 4, 5 \& $6 \%$. Mix design dikerjakan dengan menggunakan metode American Concrete Institute (ACI). Pengujian kuat tekan dan lentur dilakukan setelah perawatan beton (curing) selama 28 hari. Pengujian dan analisis kuat tekan didasarkan pada SNI-19742011. Pengujian kuat lentur mengacu pada SNI-4431-2011 yang sedikit dimodifikasi dengan menambahkan baja tulangan polos ke dalam beton. Tegangan pada beton diketahui dengan analisis berdasarkan teori elastistas. Hasil penelitian menunjukkan bahwa semakin banyak presentase bahan tambah serat baja canai dingin yang diberikan ke dalam campuran beton justru menurunkan kekuatan tekannya. Bahkan pada tambahan serat yang terlampau banyak yaitu presentase 5\% dan $6 \%$ justru akan membuat kuat tekan beton berada di bawah kuat tekan beton rencana. Semakin banyak presentase bahan tambah serat baja canai dingin yang diberikan meningkatkan kuat lentur beton. Presentase optimum untuk kuat tekan yaitu pada $1 \%$ sedangkan kuat lentur adalah $6 \%$.
\end{abstract}

Kata kunci : Baja Canai Dingin, Kuat Tekan, Kuat Lentur

\section{Pendahuluan}

Beton merupakan material konstruksi yang bersifat getas. Kombinasinya dengan baja pada material beton bertulang menjadikan beton yang getas menjadi daktail. Pada struktur beton bertulang, beton bekerja menahan tekan sedangkan baja melawan tarik (Nasution, 2009). Dengan bekerjanya kedua material tersebut sesuai dengan tugasnya masing-masing maka beton bertulang dapat digunakan sebagasi struktur konstruksi bangunan dengan perilaku struktur yang beraneka raga termasuk balok atau girder. Namun pada kombinasi kedua material ini, beton hanya bekerja separuhnya saja yaitu serat tekan saja sedangkan serat tarik beton tidak berfungsi. Bisa dibayangkan berapa volume beton yang tidak berfungsi dan hanya membebani struktur beton bertulang tersebut (T.Y. Lin, 1978).

Kelemahan beton tersebut mengakibatkan struktur beton bertulang mengalami retak lentur. Hal ini dikhawatirkan berpotensi menurunkan ketahanan struktural dan menyebabkan korosi pada baja tulangan karena terbukanya selimut beton. Untuk meminimalisir terjadinya retak maka kekuatan lentur (flexural strength) beton perlu ditingkatkan. Salah satu caranya yaitu dengan menambahkan bahan serat berkekuatan tarik tinggi ke dalam beton

Baja canai dingin atau dikenal sebagai cold formed steel merupakan salah satu jenis material baja yang mempunyai kuat tarik berada pada kisaran 500-800 MPa (Reno, 2017). Jenis baja ini juga lebih dikenal sebagai baja mutu tinggi disebabkan kekuatan leleh dan tariknya tersebut. Satu batang baja ringan yang beredar di pasaran biasanya mempunyai panjang maksimum $6 \mathrm{~m}$ sehubungan dengan kemudahan material dalam proses pengangkutan dan pendistribusiannya. Pada pengerjaan konstruksi struktur truss yang sering menggunakan material baja canai dingin penyambungan dan pemotongan batang profil disesuaikan dengan panjang frame. Penyambungan dilakukan pada panjang frame lebih dari $6 \mathrm{~m}$ sedangkan pemotongan dikerjakan untuk frame kurang dari $6 \mathrm{~m}$. Pemotongan akibat kelebihan material tersebut sering kali menimbulkan waste cukup banyak pada proyek-proyek konstruksi baja canai dingin, terlebih pada proyek struktur truss atap pada bentang-bentang kecil dengan frame yang rumit. Waste tersebut pada akhirnya hanya menghasilkan limbah produksi yang hanya menumpuk di gudang-gudang baik pada fabrikator 
maupun aplikator perusahaan konstruksi baja canai dingin dan menunggu untuk dikilokan ke pengepul barang rongsokan dengan harga yang sangat miring.

Ketebalan penampang profilnya yang tipis, membuat waste baja ringan dapat dibentuk menjadi berbagai bentuk termasuk bergelombang. Kuat tarik dan tekan baja yang tinggi berpengaruh terhadap kemampuan tekan dan lentur beton. Bentuknya yang bergelombang mempengaruhi ikatan antar partikel beton pada struktur balok lentur sehingga ketika diberi beban dan sudah berada pada batas retak maka retak tersebut mampu ditahan oleh gelombang-gelombang serat baja canai dingin yang dicampur ke dalam beton bertulang.

Berdasarkan latar belakang masalah diatas maka tujuan penelitian yaitu :

a. Mengetahui bagaimana pengaruh campuran serat baja canai dingin bergelombang dengan presentase $1,2,3,4,5 \& 6 \%$ terhadap kuat tekan beton

b. Mengetahui bagaimana pengaruh campuran serat baja canai dingin bergelombang dengan presentase $1,2,3,4.5, \& 6 \%$ terhadap tahanan lentur beton bertulang.

c. Mengetahui bagaimana pengaruh serat baja canai dingin berfelombang dengan presentase 1 , $2,3,4,5, \& 6 \%$ terhadap kuat lentur beton.

d. Mengetahui presentase optimum penambahan serat baja canai dingin bergelombang pada kuat tekan dan lentur beton.

\section{Metode}

\subsection{Bagan alir Penelitian}

Berikut ditampilkan bagan alir penelitian ini.

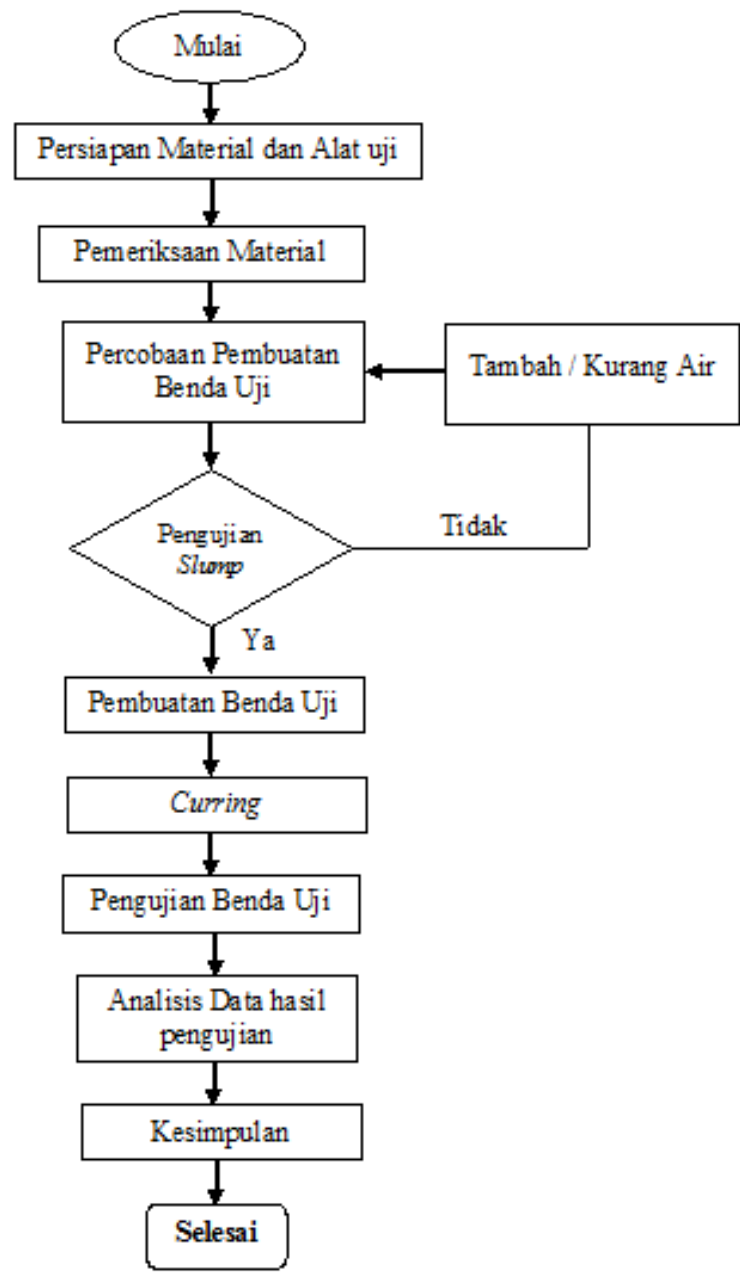

Gambar 1. Bagan alir penelitian

\subsection{Pemeriksaan Benda Uji}

\subsubsection{Pemeriksaan Agregat Halus}

1. Pemeriksaan kandungan lumpur dalam pasir

PUBI Pasal 11 (1982) mensyaratkan kandungan lumpur dalam pasir tidak boleh lebih dari 5\%. Oleh karena itu perlu dilakukan pemeriksaan kadar lumpur material pasir. Apabila tidak memenuhi persyaratan maka pasi $\mathrm{r}$ tersebut dapat dicuci terlebih dahulu. Persamaan untuk menghitung menghitung presentase kandungan lumpur adalah sebagai berikut :

$$
\mathrm{W}_{\mathrm{l}}=\frac{\mathrm{V}_{\mathrm{L}}}{\mathrm{V}_{\mathrm{P}}} \times 100 \%
$$

Keterangan :

$\mathrm{W}_{1}=$ Kandungan lumpur dalam pasir $(\%)$

$\mathrm{V}_{\mathrm{L}}=$ Volume endapan lumpur sekitar (cc)

$\mathrm{V}_{\mathrm{P}}=$ Volume pasir semula (cc)

\section{Pemeriksaan SSD pasir}

Pemeriksaan ini dilakukan untuk mengetahui apakah agregat halus yang digunakan dalam kondisi "SSD" (Saturated Surface Dry). Dengan pengujian ini maka diperoleh pasir yang sesuai 
sebagai bahan campuran adukan beton. Hal ini berhubungan dengan kandungan air yang terdapat pada pasir. Gambar 2 menampilkan kondisi pasir sebagai material uji.

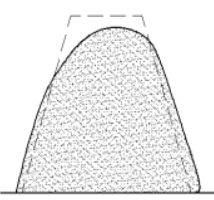

(a)

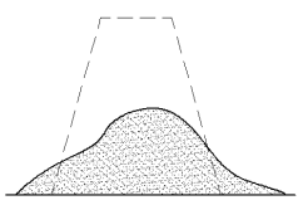

(b)

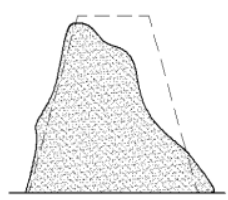

(c)
Gambar 2. Kriteria benda uji SSD pasir Sumber : PUBI 1982

Keterangan :
(a) = Pasir Basah
(b) = Pasir Kering
(c) $=$ Pasir SSD (kondisi ideal)

3. Pemeriksaan Modulus Halus Butiran (MHB)

pasir

Pemeriksaan MHB dilakukan dengan uji nalisis saringan. Hal ini dilakukan guna mengetahui distribusi butiran agregat halus. Angka MHB menunjukkan besarnya diameter butiran material uji yang digunakan. Nilai MHB ditentukan dengan persamaan :

$$
\text { MHB pasir }=\frac{\text { Berat butir tertinggal }}{100}
$$

\subsubsection{Pemeriksaan Agregat Kasar}

1. Pemeriksaan berat isi agregat kasar

Pengujian dilakukan untuk mengetahui berat volume kerikil. Persamaan menghitung berat volume yaitu :

$$
\text { B isi }=\frac{\mathrm{W}_{\text {Kerikil }}}{\mathrm{V}_{\text {Kerikil }}}
$$

Keterangan :

$\mathrm{B}_{\text {isi }} \quad$ : Berat isi kerikil $\left(\mathrm{gr} / \mathrm{cm}^{3}\right)$

$\mathrm{W}_{\text {Kerikil }}$ : Berat kerikil (gr)

$\mathrm{V}_{\text {Kerikil }}:$ Volume kerikil $\left(\mathrm{cm}^{3}\right)$

2. Pemeriksaan Modulus Halus Butiran (MHB)

kerikil

Pemeriksaan MHB dilakukan dengan uji nalisis saringan. Hal ini dilakukan guna mengetahui distribusi butiran agregat halus. Angka MHB menunjukkan besarnya diameter butiran material uji yang digunakan.

$$
\mathrm{MHB}_{\text {Kerikil }}=\frac{\text { Berat butir tertinggal }}{100}
$$

\subsection{Mix Design}

Metode rancangan adukan beton yang dipakai dalam penelitian ini adalah metode ACI (American Concrete Institute).

2.3.1 Menghitung kuat tekan rata-rata beton dengan nilai margin

Kuat tekan rata-rata yang disyaratkan dan nilai margin tergantung dari tingkat pengawasan mutu. dan volume pekerjaan beton. Nilai margin (m) ditetapkan dengan menggunakan rumus:

$\mathrm{m}=1,64 \mathrm{Sd}$

Keterangan:

$\mathrm{Sd}=$ nilai deviasi standar

Tabel 1. Deviasi Standar Berdasarkan Volume Pekerjaan dan Mutu Pelaksanaan

\begin{tabular}{ccccc}
\hline \multicolumn{2}{c}{ Volume pekerjaan } & \multicolumn{3}{c}{ Mutu pelaksanaan } \\
\hline Klasifikasi & $\mathbf{M}^{\mathbf{3}}$ & Baik sekali & Baik & Cukup \\
\hline Kecil & $<1000$ & $45<s=55$ & $55<s=65$ & $65<s=85$ \\
Sedang & $1000-3000$ & $35<s=45$ & $45<s=55$ & $55<s=75$ \\
Besar & $>3000$ & $25<s=35$ & $35<s=45$ & $45<s=65$ \\
\hline
\end{tabular}

Sumber : ACI 211-11

Kuat tekan rata-rata beton diperhitungkan dengan persamaan :

$$
\begin{gathered}
\mathrm{f}^{\prime} \mathrm{cr}=\mathrm{f} \mathrm{f}^{\prime} \mathrm{c}+\mathrm{m} \\
\mathrm{f}^{\prime} \mathrm{cr}=\mathrm{f}^{\prime} \mathrm{c}+1,64 \mathrm{Sd}
\end{gathered}
$$

Keterangan :

$\mathrm{f}^{\prime}$ 'cr = Kuat tekan rata-rata perlu (MPa)

$\mathrm{f}^{\prime} \mathrm{c}=$ Kuat tekan rencana $(\mathrm{MPa})$

$\mathrm{m} \quad=$ Margin

$\mathrm{Sd} \quad=$ Nilai deviasi strandar

\subsubsection{Nilai Slump}

Kelecakan adukan benton ditentukan supaya workability atau proses pencampuran beton mudah untuk dilaksanakan. Tingkat kelecakan adukan beton tersebut dapat ditentukan dengan nilai slump. Masing-masing jenis konstruksi mempunyai kebutuhan nilai slump yang berbeda seperti yang ditunjukkan pada Tabel 2.

Tabel 2. Nilai Slump Berbagai Jenis Konstruksi

\begin{tabular}{lcc}
\hline \multicolumn{1}{c}{ Jenis Konstruksi } & \multicolumn{2}{c}{ Slump $(\mathrm{mm})$} \\
\cline { 2 - 3 } & Min & Maks \\
\hline $\begin{array}{l}\text { Pondasi bertulang, } \\
\text { dinding, tiang }\end{array}$ & 5 & 12,5 \\
$\begin{array}{l}\text { Tiang pondasi tak } \\
\text { bertulang }\end{array}$ & 2,5 & 10 \\
$\begin{array}{l}\text { Pelat, balok, kolom } \\
\text { Beton untuk jalan } \\
\text { (pavement) }\end{array}$ & 7,5 & 15 \\
\end{tabular}


Beton massa

2,5 7,5

Sumber : ACI 211-11

\subsubsection{Keperluan Air Tiap $m^{3}$ Beton}

Kebutuhan air ditentukan berdasarkan diameter agregat kasar maksimum dan nilai slump rencana. Volume air yang diperlukan dalam campuran pembuatan beton dapat dilihat pada Tabel 3 .

Tabel 3. Keperluan Air Tiap $m^{3}$ campuran beton

\begin{tabular}{|c|c|c|c|c|c|c|c|c|}
\hline \multirow[t]{2}{*}{ Slump (mm) } & \multicolumn{8}{|c|}{$\begin{array}{c}\text { Air yang diperlikan tiap m adukan beton ( } 1 \mathrm{t} / \mathrm{kg}) \text { untuk } \\
\text { ukuran agregat maks (mm) }\end{array}$} \\
\hline & 9,6 & 12,5 & 19,6 & 25 & 38,1 & 50 & 76,2 & 150 \\
\hline \multicolumn{9}{|c|}{ Beton biasa (non air entrained) } \\
\hline $2,5-5,0$ & 213 & 203 & 188 & 183 & 168 & 157 & 147 & 127 \\
\hline $7,5-10,0$ & 234 & 223 & 208 & 198 & 183 & 173 & 163 & 142 \\
\hline $15-17,5$ & 248 & 234 & 218 & 208 & 193 & 183 & 173 & 152 \\
\hline $\begin{array}{l}\text { Udara terperangkap } \\
\qquad \%)\end{array}$ & 3,0 & 2,5 & 2,0 & 1,5 & 1,0 & 0,5 & 0,3 & 0,2 \\
\hline \multicolumn{9}{|c|}{ Beton bergelembung udara (air entrained) } \\
\hline $2,5-5,0$ & 188 & 183 & 168 & 157 & 147 & 137 & 127 & 111 \\
\hline $7,5-10,0$ & 208 & 198 & 183 & 173 & 163 & 152 & 142 & 122 \\
\hline $15,0-17,5$ & 218 & 208 & 193 & 183 & 173 & 163 & 152 & 132 \\
\hline $\begin{array}{l}\text { Udara terperangkap } \\
\qquad(\%)\end{array}$ & 8 & 7 & 6 & 5 & 4,5 & 4 & 3,5 & 3 \\
\hline
\end{tabular}

Sumber : ACI 211-11

\subsubsection{Faktor Air Semen (FAS)}

Faktor air semen ialah perbandingan berat antara air dan semen portland di dalam campuran adukan beton. Faktor Air Semen ditentukan menurut Tabel 4.

Tabel 4. Faktor Air Semen Beton 28 Hari

\begin{tabular}{|c|c|c|}
\hline \multirow{2}{*}{ FAS } & \multicolumn{2}{|c|}{$\begin{array}{l}\text { Kuat Tekan Beton } \\
\text { Umur } 28 \text { hari }\end{array}$} \\
\hline & $\begin{array}{l}\text { Beton non air } \\
\text { entrained }\end{array}$ & $\begin{array}{l}\text { Beton air } \\
\text { entrained }\end{array}$ \\
\hline 0,360 & 420 & 340 \\
\hline 0,450 & 350 & 280 \\
\hline 0,540 & 280 & 225 \\
\hline 0,630 & 225 & 185 \\
\hline 0,720 & 175 & 140 \\
\hline 0,810 & 140 & 115 \\
\hline
\end{tabular}

Sumber : ACI 211-11

\subsubsection{Kebutuhan Kerkil Per $\mathrm{m}^{3}$ Beton}

Berat kerikil pada campuran pembuatan beton ditentukan berdasarkan nilai MHB Pasir dan ukuran butir maksimum yang digunakan.

Tabel 5. Kebutuhan Agregat Tiap $m^{3}$ Adukan Beton

\begin{tabular}{cc}
\hline Agregat & Kebutuhan agregat kasar \\
kasar & berdasarkan nilai MHB Pasir \\
$(\mathrm{mm})$ & \\
\hline
\end{tabular}

\begin{tabular}{lllll} 
& 2,40 & 2,60 & 2,80 & 3,00 \\
9,5 & 0,46 & 0,44 & 0,42 & 0,40 \\
12,7 & 0,55 & 0,53 & 0,51 & 0,49 \\
19,2 & 0,65 & 0,63 & 0,61 & 0,59 \\
25,0 & 0,70 & 0,68 & 0,66 & 0,64 \\
38,1 & 0,76 & 0,74 & 0,72 & 0,70 \\
50,0 & 0,79 & 0,77 & 0,75 & 0,73 \\
76,0 & 0,84 & 0,82 & 0,82 & 0,78 \\
150 & 0,90 & 0,88 & 0,86 & 0,84 \\
\hline \multicolumn{5}{l}{ Sumber : ACI 211-11 }
\end{tabular}

\subsubsection{Kebutuhan Pasir}

Volume pasir yang diperlukan dalam pembuatan $1 \mathrm{~m}^{3}$ beton dapat ditrntukan menggunakan persamaan:

Vol. Pasir $=1$ - (vol. Air + vol. Udara + vol. Semen + vol.

Keterangan :

$$
\text { Kerikil) }
$$

Vol.Pasir $=$ Volume pasir $1 \mathrm{~m}^{3}$ beton $\left(\mathrm{m}^{3}\right)$

Vol.Air $\quad=$ Volume air $1 \mathrm{~m}^{3}$ beton $\left(\mathrm{m}^{3}\right)$

Vol.Udara $=$ Volume udara $1 \mathrm{~m}^{3}$ beton $\left(\mathrm{m}^{3}\right)$

Vol.semen $=$ Volume semen $1 \mathrm{~m}^{3}$ beton $\left(\mathrm{m}^{3}\right)$

Vol. ${ }_{\text {Kerikil }}=$ Volume kerikil $1 \mathrm{~m}^{3}$ beton $\left(\mathrm{m}^{3}\right)$

Sedangkan kebutuhan berat pasir dalam campuran beton diperoleh dengan persamaan :

$$
\mathrm{W}_{\text {pasir }}=\mathrm{Vol}_{\text {pasir }} \times \mathrm{BJ}_{\text {pasir }}
$$

Keterangan :

$\mathrm{W}_{\text {pasir }}=$ Berat pasir per $1 \mathrm{~m}^{3}$ beton $(\mathrm{Kg})$

Vol.pasir $=$ Volume pasir $1 \mathrm{~m}^{3}$ beton $\left(\mathrm{m}^{3}\right)$

$B J_{\text {pasir }}=$ Berat Jenis Pasir $\left(\mathrm{Kg} / \mathrm{m}^{3}\right)$

\subsubsection{Berat Isi Beton}

$\mathrm{W}_{\text {beton }}=\mathrm{W}_{\text {semen }}+\mathrm{W}_{\text {pasir }}+\mathrm{W}_{\text {kerikil }}+\mathrm{W}_{\text {air }}$

Keterangan :

$\mathrm{W}_{\text {beton }}=$ Berat isi beton $\left(\mathrm{Kg} / \mathrm{m}^{3}\right)$

$\mathrm{W}_{\text {semen }}=$ Berat semen per $\mathrm{m}^{3}$ beton $\left(\mathrm{Kg} / \mathrm{m}^{3}\right)$

$\mathrm{W}_{\text {pasir }}=\mathrm{B}$ erat pasir per $\mathrm{m}^{3}$ beton $\left(\mathrm{Kg} / \mathrm{m}^{3}\right)$

$\mathrm{W}_{\text {air }}=$ Berat air per $\mathrm{m}^{3}$ beton $\left(\mathrm{Kg} / \mathrm{m}^{3}\right)$

\subsubsection{Serat Baja Canai Dingin}

Waste baja canai dingin dibentuk menjadi seratserat bergelombang untuk kemudian ditambahkan ke dalam campuran beton normal sesuai dengan presentase yang telah ditentukan. Serat-serat baja canai dingin dingin bergelombang ditunjukkan pada Gambar 3. 


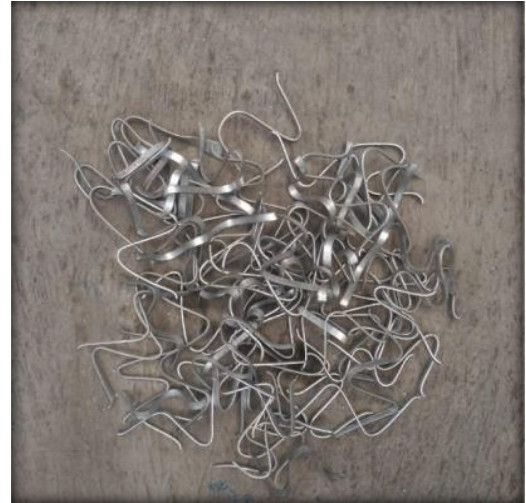

Gambar 3. Serat baja canai dingin bergelombang

Detail ukuran serat baja canai dingin begelombang adalah sebagai berikut.

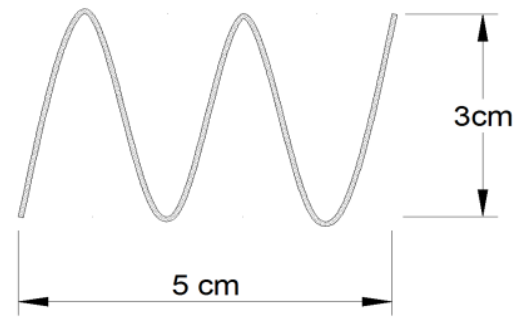

Gambar 4. Detail dimensi serat baja canai dingin

Penambahan serat baja canai dingin bergelombang ditentukan terhadap berat semen yang diperlukan dalam $1 \mathrm{~m}^{3}$ beton normal. Dihitung dengan persamaan :

$$
\mathrm{W}_{\text {serat }}=\frac{\% \text { Serat }}{100} \times \mathrm{W} \text { semen }
$$

Keterangan :

$\mathrm{W}_{\text {serat }}=$ Berat serat baja canai dingain $\left(\mathrm{Kg} / \mathrm{m}^{3}\right)$

$\%$ serat $=$ Presentase penambahan serat baja canai dingin $(\%)$

$\mathrm{W}_{\text {semen }}=$ Berat semen per $\mathrm{m}^{3}$ beton $\left(\mathrm{Kg} / \mathrm{m}^{3}\right)$

\subsection{Uji Kuat Tekan Beton}

Menurut SNI 1974: 2011, kuat tekan benda uji dihitung dengan membagi beban maksimum yang diterima selama pengujian dengan luas penampang benda uji. Kuat tekan benda uji adalah tegangan desak ( $\mathrm{f}^{\prime} \mathrm{c}$ ) tertinggi yang dicapai oleh beton pada umur 28 hari. Benda uji yang digunakan yaitu silinder beton dengan diameter $150 \mathrm{~mm}$ dan tinggi $300 \mathrm{~mm}$. Sketsa silinder beton dapat dilihat pada Gambar 5.

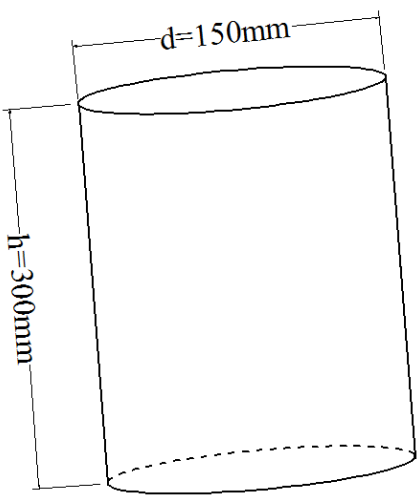

Gambar 5. Sketsa benda uji kuat tekan

Berikut ditampilkan prosedur pengujian kuat tekan silinder beton.

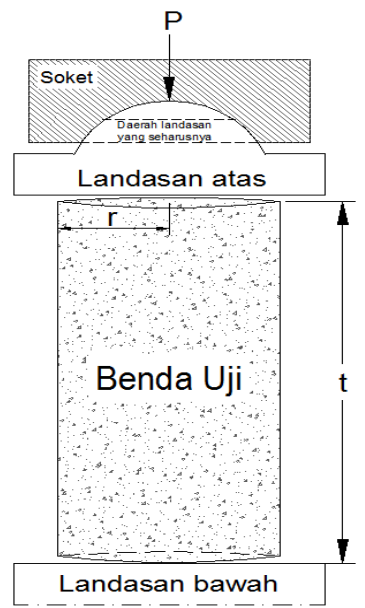

Gambar 6. Pengujian kuat tekan beton Sumber : SNI 1974:2011

Nilai kuat tekan beton dapat dihitung dengan rumus:

$$
f^{\prime} c=\frac{P}{A}
$$

Keterangan:

f'c = Nilai kuat tekan beton $(\mathrm{MPa})$

$\mathrm{P}=$ Gaya tekan aksial $(\mathrm{N})$

$\mathrm{A}=$ Luas penampang benda uji $(\mathrm{mm})$

\subsection{Uji Kuat Lentur Beton}

Menurut SNI 4431:2011, kuat lentur beton adalah kemampuan beton yang diletakan pada dua perletakan untuk menahan gaya dengan arah tegak lurus sumbu benda uji sampai benda uji patah. Penelitian ini menggunakan uji kuat lentur beton dengan metode SNI 4431:2011 yang sedikit dimodifikasi dengan ditambahkan penulangan baja polos di dalamnya. Benda uji balok beton bertulang dapat dilihat pada Gambar 7. 


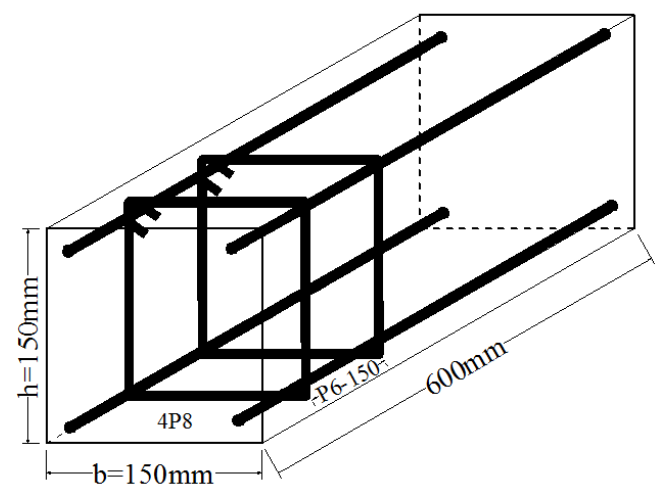

Gambar 7. Sketsa benda uji kuat lentur

Ilustrasi pengujian kuat lentur beton ditunjukkan sebagai berikut.

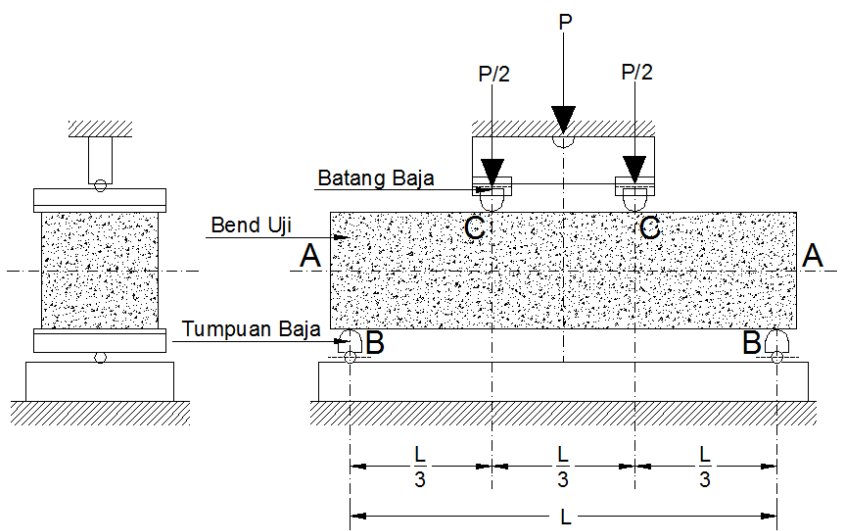

(b) Melintang

(a) Memanjang

Gambar 8. Pengujian kuat lentur beton

Sumber : SNI 4431:2011

Keterangan gambar:

$\mathrm{A}=$ Sumbu memanjang $(\mathrm{mm})$

$\mathrm{B}=$ Titik-titik perletakan $(\mathrm{mm})$

$\mathrm{C}=$ Titik-titik pembebanan $(\mathrm{mm})$

Momen lentur balok beton bertulang dapat dihitung dengan menggunakan rumus:

$$
\mathrm{M}=\frac{W d, L^{2}}{8}+\frac{P, L}{6}
$$

Keterangan :

$\mathrm{M} \quad=$ Momen lentur beton bertulang $(\mathrm{Nmm})$

$\mathrm{Wd}=$ Berat sendiri Balok $(\mathrm{N} / \mathrm{mm})$

$\mathrm{P} \quad=$ Beban maksimum $(\mathrm{N})$

$\mathrm{L} \quad=$ Panjang bentang benda uji $(\mathrm{mm})$

$\mathrm{b} \quad=$ Lebar benda uji $(\mathrm{mm})$

Kekuatan lentur beton pada penampang dianalisis berdasarkan teori elastisitas balok komposit. Hal tersebut dikarenakan sample uji meupakan struktur komposit antara beton (concrete) dan baja tulangan (rebar).

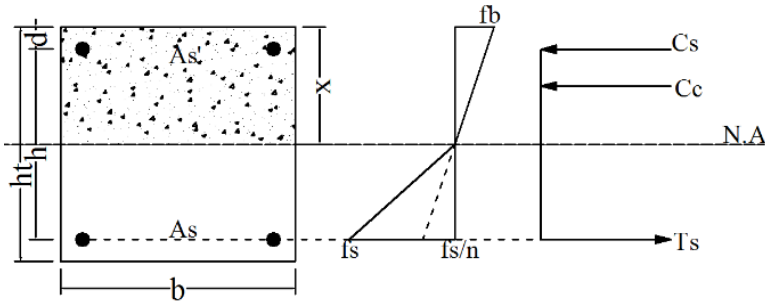

Gambar 9. Analisis penampang balok

Berlaku persamaan sebagai berikut :

$$
\left\{\left(\text { b.x. } \frac{x}{2}\right)+(\text { n.As' })(\mathrm{x}-\mathrm{d})=(\mathrm{n} . \mathrm{As})(\mathrm{h}-\mathrm{x})\right\}
$$

Keterangan :

$\mathrm{B}=$ Lebar benda uji ( $\mathrm{mm})$

$\mathrm{x}=$ Tinggi beton desak $(\mathrm{mm})$

$\mathrm{n} \quad=$ Jumlah tulangan tarik atau desak (bh)

As' = Luasan baja desak $\left(\mathrm{mm}^{2}\right)$

As $\quad=$ Luasan baja tarik $\left(\mathrm{mm}^{2}\right)$

$\mathrm{h} \quad=$ Tinggi efektif penampang balok $(\mathrm{mm})$

ht = Tinggi penampang balok $9 \mathrm{~mm}$ )

Tegangan desak beton (compression strength) dapat dihitung sebagai berikut :

$$
f^{\prime}{ }_{c}=\frac{M \cdot y c}{I x}
$$

Keterangan :

$\mathrm{f}^{\prime} \mathrm{c} \quad=$ Kuat tekan beton (MPa)

$\mathrm{M} \quad=$ Momen Lentur balok (Nmm)

$\mathrm{y}_{\mathrm{c}} \quad=$ Lengan tepi berat beton desak terhadap garis netral penampang balok (mm)

$\mathrm{I}_{\mathrm{x}} \quad=$ Momen Inersia Sumbu $\mathrm{x}$ penampang desak beton $\left(\mathrm{mm}^{4}\right)$

Menurut ACI korelasi antara tegangan desak dengan tegangan lentur beton (flexural strength) dihitung dengan persamaan :

Keterangan :

$$
\mathrm{fr}=0,9 . \mathrm{f}^{\prime} \mathrm{c}^{0,5}
$$

$\mathrm{f}^{\prime} \mathrm{r}=$ Kuat lentur beton $(\mathrm{MPa})$

$\mathrm{f}^{\prime} \mathrm{c}=$ Kuat tekan beton $(\mathrm{MPa})$

\section{Hasil dan Pembahasan}

\subsection{Pemeriksaan Material Benda Uji}

3.1.1 Pengujian Agregat Halus

1. Pengujian kadar lumpur pasir

Pasir yang digunakan sebagai benda uji berasal dari sunga progo, Yogyakarta. Dari hasil pengujian diperoleh :

$\mathrm{V}_{\mathrm{P}}=450 \mathrm{cc}$

$\mathrm{V}_{\mathrm{L}}=11 \mathrm{cc}$

$\mathrm{W}_{1}=\frac{\mathrm{V}_{\mathrm{L}}}{\mathrm{V}_{\mathrm{P}}} \times 100$

$$
=\frac{11}{450} \times 100 \%
$$


$=2,4 \%$

Kadar lumpur dalam pasir kurang dari $5 \%$ sehingga memenuhi persyaratan dipakai sebagai benda uji.

2. Pemeriksaan SSD Pasir

Pengujian pasir menunjukkan agregat halus termasuk pada kondisi ideal (SSD).

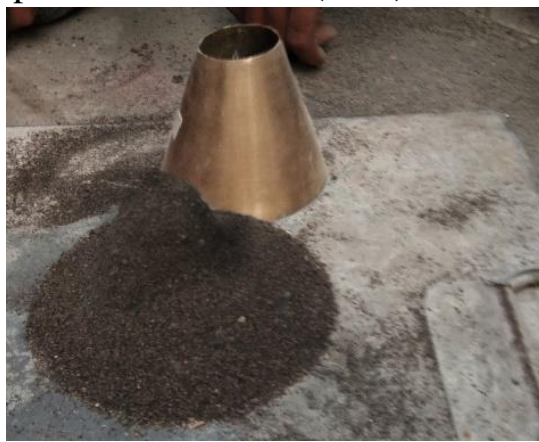

Gambar 10. Hasil Pengujian SSD Pasir

4. Pemeriksaan Modulus Halus Butiran Pasir

Modulus Halus Butiran (MHB) yaitu 2,8 dan berdasarkan grafik gradasi termasuk dalam jenis pasir Agak Kasar.

\subsubsection{Pengujian Agregat Kasar}

1. Pemeriksaan berat isi agregat kasar

Berat isi kerikil diperhitungkan :

$$
\begin{aligned}
\mathrm{W}_{\text {kerikil }}= & 7850 \mathrm{gr} \\
\mathrm{V}_{\text {kerikil }}= & \frac{1}{4} \times \pi \times d^{2} \times \mathrm{t} \\
& =\frac{1}{4} \times \pi \times 15^{2} \times 30 \\
& =5298,75 \mathrm{~cm}^{3} \\
B \text { isi } & =\frac{\mathrm{W}_{\text {Kerikil }}}{\mathrm{V}_{\text {Kerikil }}} \\
& =\frac{7830}{5298,75} \\
& =1,5 \mathrm{gr} / \mathrm{cm}^{3}
\end{aligned}
$$

2. Pemeriksaan MHB Kerikil

Dari pemeriksaan MHB kerikil diperoleh sebesar 5,88. Berdasarkan grafik gradasi agregat kasar kerikil uji termasuk dalam agregat Kasar.

\subsection{Mix Design}

\subsubsection{Kuat tekan rata-rata perlu ( $f^{\prime} \mathrm{cr}$ )}

Volume pekerjaan beton pada penelitian ini yaitu $0,501 \mathrm{~m}^{3}$ kurang dari $1000 \mathrm{~m}^{3}$ sehingga termasuk dalam kategori kecil. Mutu pelaksanaan direncanakan Baik Sekali. Dari kedua hal tersebut maka diambil nilai deviasi standar 52. Kuat tekan rata-rata perlu diperoleh dengan rumus :

$$
\begin{aligned}
\mathrm{f}^{\prime} \mathrm{cr} & =\mathrm{f}^{\prime} \mathrm{c}+\mathrm{m} \\
& =\mathrm{f}^{\prime} \mathrm{c}+1,6 \mathrm{Sd} \\
& =250+1,6(52) \\
& =333,2 \mathrm{~kg} / \mathrm{cm}^{2} \approx 33,32 \mathrm{MPa}
\end{aligned}
$$

\subsubsection{Nilai Slump Rencana}

Penelitian ini memfokuskan pada beton struktural (konstruksi balok dan kolom). Nilai slump harus berada diantara rentang 7,5-15 cm. Dari range nilai slump tersebut diambil nilai slump rencana yaitu $10 \mathrm{~cm} \approx 100 \mathrm{~mm}$.

\subsubsection{Kebutuhan Air}

Dimensi maksimum aggregat kasar yang digunakan pada mix design yaitu $25 \mathrm{~mm}$, nilai slump rencana $10 \mathrm{~cm}$. Berdasarkan Tabel diperoleh berat air $\left(\mathrm{W}_{\text {air }}\right)=198 \mathrm{lt} / \mathrm{m}^{3}$ beton dan perkiraan udara terperangkap yaitu 1,5\%.

\subsubsection{Nilai FAS (Faktor Air Semen)}

Nilai FAS ditentukan menggunakan Tabel dengan nilai $f^{\prime} \mathrm{cr}=330 \mathrm{~kg} / \mathrm{cm}^{2}$ dan termasuk beton non air (entrained). Dengan interpolasi berdasarkan rentang $f^{\prime} \mathrm{cr}=280-350 \mathrm{~kg} / \mathrm{cm}^{2}$ maka diperoleh nilai $\mathrm{FAS}=0,5$.

\subsubsection{Kebutuhan semen}

Berat air yang diperlukan, $\mathrm{W}$ air $=198 \mathrm{lt} / \mathrm{m}^{3} \approx$ $198 \mathrm{~kg} / \mathrm{m}^{3}$. Kebutuhan semen tiap $\mathrm{m}^{3}$ beton dihitung :

$$
\begin{aligned}
\text { FAS } & =\frac{W \text { air }}{W \text { semen }} \\
\mathrm{W}_{\text {semen }} & =\frac{W \text { air }}{F A S} \\
& =\frac{198}{0,5} \\
& =396 \mathrm{~kg} / \mathrm{m}^{3} \\
\mathrm{~V}_{\text {semen }} & =\frac{W \text { semen }}{B j \text { Semen }} \\
& =\frac{396}{3,15} \\
& =0,126 \mathrm{~m}^{3}
\end{aligned}
$$

\subsubsection{Kebutuhan Agregat Kasar}

Pada penelitian digunakan pasir dengan MHB 2,8 serta ukuran agregat terbesar $25 \mathrm{~mm}$. Menurut Tabel diperoleh kebutuhan berat kerikil tiap $1 \mathrm{~m}^{3}$ beton adalah 0,66 .

\subsubsection{Kebutuhan Pasir}

Kebutuhan pasir dalam campuran beton dihitung : Volume pasir $=1-$ (vol. Air + vol. Udara + vol.

$$
\text { Semen }+ \text { vol. Kerikil })
$$$$
=1-(0,198+0,015+0,126+
$$$$
0.381)
$$$$
=0,281 \mathrm{~m}^{3}
$$

$\mathrm{W}_{\text {pasir }} \quad=$ volume pasir $\mathrm{x} \mathrm{BJ}$ pasir $=0,281 \times 2,5$

$$
=0,701 \text { ton }=701,291 \mathrm{~kg} / \mathrm{m}^{3}
$$

3.2.8 Kebutuhan Material $1 \mathrm{~m}^{3}$ beton normal

$$
\mathrm{W}_{\text {semen }}=396,000 \mathrm{~kg} / \mathrm{m}^{3}
$$




$$
\begin{array}{ll}
\mathrm{W}_{\text {pasir }} & =701,291 \mathrm{~kg} / \mathrm{m}^{3} \\
\mathrm{~W}_{\text {kerikil total }} & =990 \mathrm{~kg} / \mathrm{m}^{3} \\
\mathrm{~W}_{\text {air }} & =198 \mathrm{liter} / \mathrm{m}^{3}=198 \mathrm{~kg} / \mathrm{m}^{3}
\end{array}
$$

3.2.9 Berat per $\mathrm{m}^{3}$ beton normal

$$
\begin{aligned}
\mathrm{W}_{\text {beton }} & =\mathrm{W}_{\text {semen }}+\mathrm{W}_{\text {pasir }}+\mathrm{W}_{\text {kerikil }}+\mathrm{W}_{\text {air }} \\
& =396,000+701,291+990+198 \\
& =2285,29 \mathrm{~kg} / \mathrm{m}^{3}
\end{aligned}
$$

3.2.10 Penambahan serat baja canai dingin

Penambahan serat baja canai dingin bergelombang dilakukan dengan presentase 1, 2, 3, $4,5 \& 6 \%$. Berikut contoh perhitungan pada penambahan serat $1 \%$.

$$
\begin{aligned}
\mathrm{W}_{1 \%} & =\frac{1}{100} \times \mathrm{W} \text { semen } \\
& =0,01 \times 396,00 \\
& =0,063 \mathrm{~kg} / \mathrm{m}^{3}
\end{aligned}
$$

Tabel 6. Kebutuhan Penambahan Serat Tiap Campuran $1 \mathrm{~m}^{3}$ Beton

\begin{tabular}{cc}
\hline $\begin{array}{c}\text { Presentase } \\
\text { Serat }(\%)\end{array}$ & $\begin{array}{c}\text { Penambahan Serat per } \mathrm{m}^{3} \\
\text { beton }\left(\mathrm{Kg} / \mathrm{m}^{3}\right)\end{array}$ \\
\hline 1 & 3,96 \\
2 & 7,92 \\
3 & 11,88 \\
4 & 15,84 \\
5 & 19,8 \\
6 & 23,76 \\
\hline
\end{tabular}

\subsection{Pengujian Slump}

Hasil pengujian nilai slump sample uji silinder beton ditunjukkan pada gambar berikut.

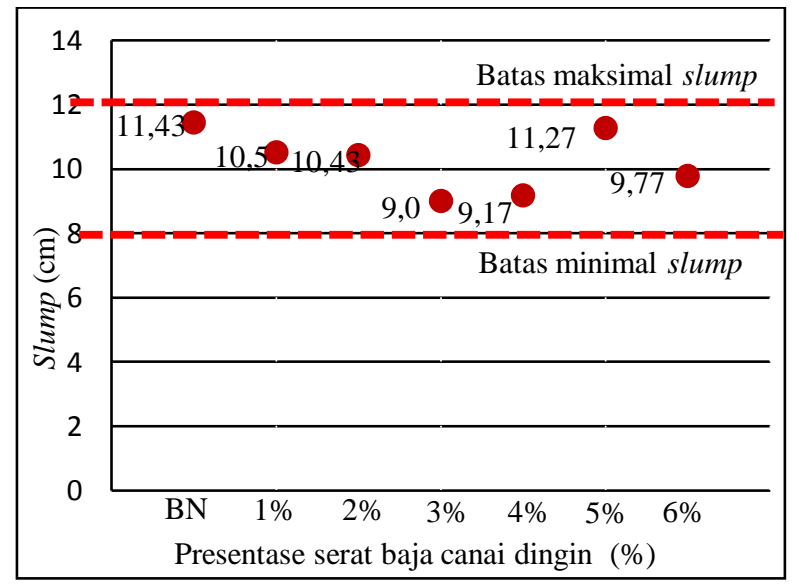

Gambar 11. Hasil pengujian slump benda uji silinder

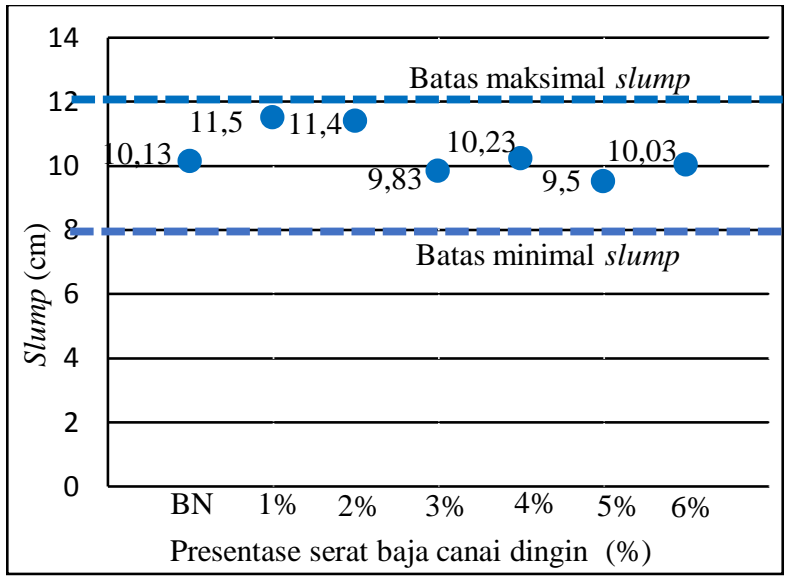

Gambar 12. Hasil pengujian slump benda uji balok

Secara keseluruhan pengujian sample silinder maupun balok beton menunjukkan bahwa nilai slump masih memenuhi persyaratan karena berada dirange $10 \pm 2 \mathrm{~cm}$. Hasil pencampuran material tersebut bisa digunakan ke tahap pembuatan benda uji.

\subsection{Pengujian Tekan Balok}

Pengujian kuat tekan beton dilakukan pada saat benda uji berumur 28 hari sehingga beton diharapkan sudah mencapai kekuatan maksimumnya. Secara keseluruhan terdapat 21 benda uji berbentuk silinder yang terdiri dari 3 sampel beton normal, 3 serat tambah $1 \%, 3$ serat tambah 2\%, 3 serat tambah 4\%, 3 serat tambah 5\%, dan 3 serat tambah $6 \%$. Pengujian kuat tekan dapat dilihat pada Gambar 13.

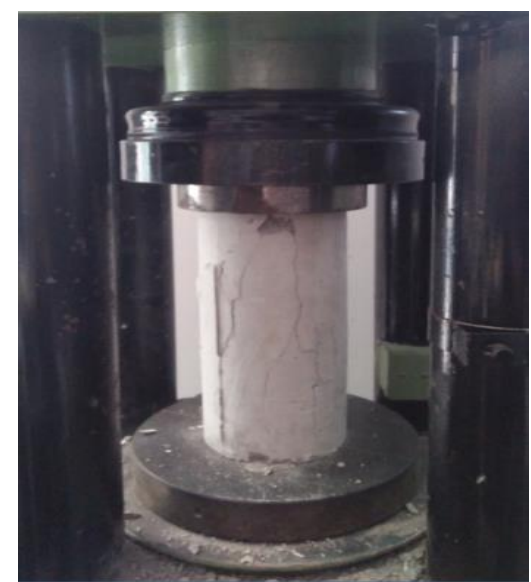

Gambar 13. Uji Tekan Silinder Beton

Berikut contoh analisis hasil pengujian kuat tekan beton normal.

$\begin{aligned} \text { Beban maksimum (P) } & =588,6 \mathrm{kN} \\ & =588600 \mathrm{~N} \\ \text { Luas Permukaan (A) } & =\frac{1}{4} \times \pi \times d^{2}\end{aligned}$ 


$$
\begin{aligned}
& =\frac{1}{4} \times \pi \times 150^{2} \\
& =17672,5 \mathrm{~mm}^{2} \\
\text { Kuat tekan (f'c) } \quad & =\frac{P}{A} \\
& =\frac{588600}{17672,5} \\
& =33,32 \mathrm{MPa}
\end{aligned}
$$

Dari ketiga benda uji diperoleh kuat tekan benda uji $1=33,32 \mathrm{MPa}$, benda uji $2=33,32 \mathrm{MPa}$ dan benda uji $3=33,32 \mathrm{MPa}$. Kuat tekan rata-rata beton normal diperhitungkan :

$$
\begin{aligned}
\text { Kuat tekan rata }- \text { rata } & =\frac{B \text { uji } 1+\mathrm{B} \mathrm{uji} 2+\mathrm{B} \text { uji } 3}{3} \\
& =\frac{33,32+33,32+33,32}{3} \\
& =33,32 \mathrm{MPa}
\end{aligned}
$$

Hasil perhitungan kuat tekan beton secara keseluruhan ditunjukkan pada Tabel.

Tabel Hasil pengujian kuat tekan beton

\begin{tabular}{lc}
\hline Jenis beton & $\begin{array}{c}\text { Kuat rekan rata-rata } \\
(\mathrm{MPa})\end{array}$ \\
\hline Beton Normal & 33,32 \\
Beton Serat 1\% & 36,66 \\
Beton Serat 2\% & 34,99 \\
Beton Serat 3\% & 35,36 \\
Beton Serat 4\% & 35,36 \\
Beton Serat 5\% & 29,25 \\
Beton Serat 6\% & 29,99 \\
\hline
\end{tabular}

Grafik kuat tekan beton normal sampai dengan beton serat $6 \%$ adalah sebagai berikut.

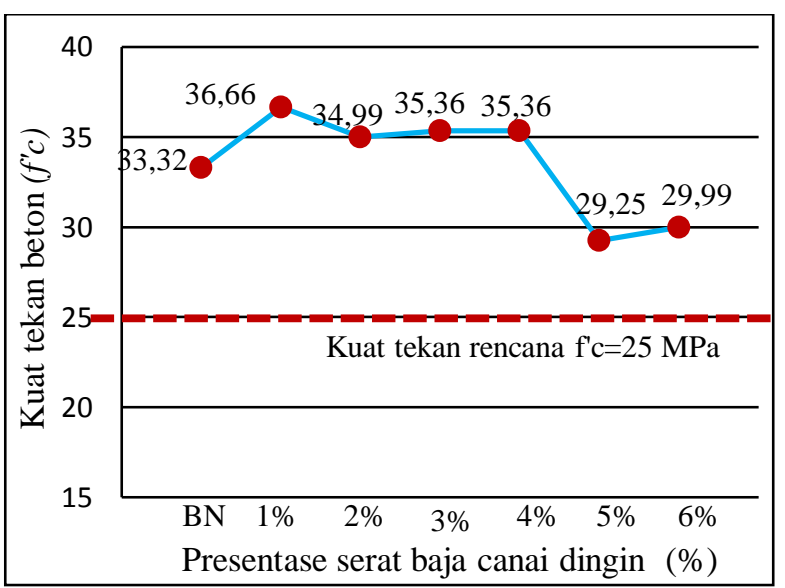

Gambar 14. Grafik kuat tekan silinder beton

Gambar 14 menunjukkan terlalu banyak tambahan serat baja yang diberikan tidak terlalu baik bagi kuat tekan beton. Presentase penambahan serat optimum untuk kuat tekan beton adalah $1 \%$. Pada presentase penambahan serat 5\% \& 6\% kekuatan tekan justru berada di bawah beton normal.

\subsection{Pengujian Kuat Lentur Balok Beton Bertulang}

Pengujian kuat lentur balok beton betulang dilakukan pada 21 benda uji yang terdiri dari 3 sampel beton normal, 3 serat tambah $1 \%, 3$ serat tambah 2\%, 3 serat tambah 4\%, 3 serat tambah 5\%, dan 3 serat tambah $6 \%$. Pengujian kuat lentur dapat dilihat pada Gambar.

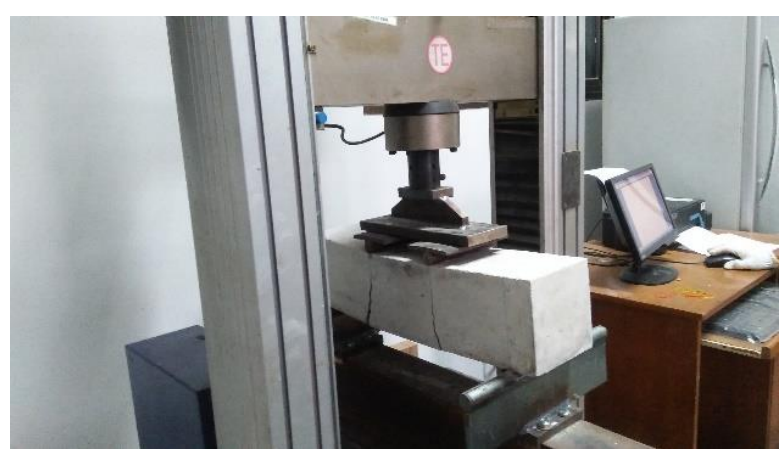

Gambar 15. Uji lentur balok beton bertulang

Pada pengujian lentur beton normal benda uji 1 diperoleh data sebagai beikut :

$$
\begin{aligned}
\text { Beban maksimum }(\mathrm{P}) & =83,45 \mathrm{kN} \\
\text { Panjang bentang }(\mathrm{L}) & =520 \mathrm{~mm} \\
& =0,52 \mathrm{~m} \\
\text { Lebar benda uji (b) } & =150 \mathrm{~mm} \\
& =0,15 \mathrm{~m} \\
\text { Tinggi benda uji }\left(\mathrm{h}_{\mathrm{t}}\right) & =150 \mathrm{~mm} \\
& =0,15 \mathrm{~m}
\end{aligned}
$$

Berat sendiri benda uji,

$\mathrm{Wd}=$ b.ht. $\mathrm{b}_{\text {isi beton bertulang }}$

$$
=0,15 \cdot 0,15 \cdot 24
$$$$
=0,018 \mathrm{kN} / \mathrm{m}
$$

Momen,

$$
\begin{aligned}
\mathrm{M}_{\mathrm{bu} 1} & =\frac{\mathrm{Wd}, \mathrm{L}^{2}}{8}+\frac{\mathrm{P}, \mathrm{L}}{6} \\
& =\frac{0,018,0,52^{2}}{8}+\frac{83,45,0,52}{6} \\
& =7,251 \mathrm{kNm}
\end{aligned}
$$

Dengan menggunakan metode perhitungan yang sama diperoleh,

Momen benda uji 1, $\mathrm{M}_{\mathrm{bu} 2}=7,145 \mathrm{kNm}$

Momen benda uji 2, $\mathrm{M}_{\mathrm{bu} 3}=7,130 \mathrm{kNm}$

Momen rata-rata yang mampu dipikul oleh beton bertulang normal diperhitungkan

$$
\begin{aligned}
M_{\text {rata2 }} & =\frac{M b u 1+M b u 2+M b u 3}{3} \\
& =\frac{7,251+7,145+7,130}{3} \\
& =7,175 \mathrm{kNm}
\end{aligned}
$$

Hasil perhitungan momen seluruh benda uji ditampilan pada Tabel 7. 
Tabel 7. Momen maksimum seluruh benda uji

\begin{tabular}{lc}
$\begin{array}{l}\text { Jenis beton } \\
\text { bertulang }\end{array}$ & $\begin{array}{c}\text { Momen } \\
(\mathrm{kNm})\end{array}$ \\
\hline Beton Normal & 7,175 \\
Beton Serat 1\% & 8,166 \\
Beton Serat 2\% & 7,879 \\
Beton Serat 3\% & 8,593 \\
Beton Serat 4\% & 8,532 \\
Beton Serat 5\% & 8,474 \\
Beton Serat 6\% & 8,633 \\
\hline
\end{tabular}

Momen maksimum tiap benda uji kemudian diplot ke dalam grafik sesuai Gambar 16.

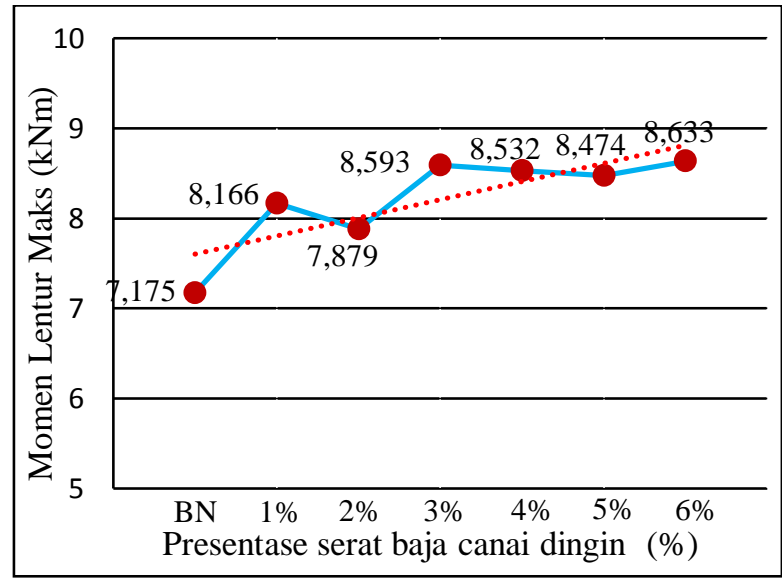

Gambar 16. Momen hasil uji lentur balok beton bertulang

Dari Gambar 16 diketahui terjadi kenaikan momen seiring dengan bertambahnya presentase serat baja yang berarti juga tahanan momen balok beton bertulang mengalami peningkatan.

Tegangan lentur beton diperhitungkan dengan analisis penampang berdasarkan teori elastisitas.

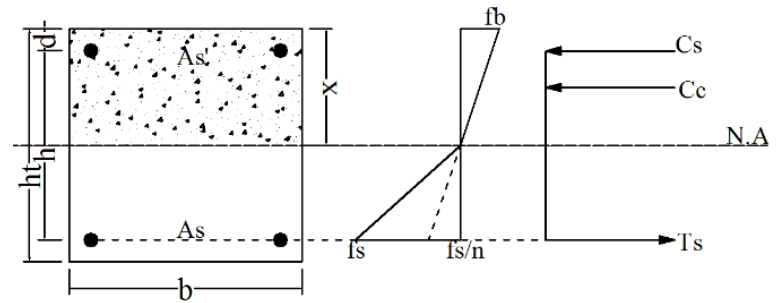

Gambar 17. Analisis penampang balok

Luasan baja tarik sama dan desak,

$$
\begin{aligned}
\text { Ass=As' } & =\frac{1}{4} \Pi \mathrm{d}^{2} \\
& =\frac{1}{4} \Pi(8)^{2} \\
& =50,24 \mathrm{~mm}^{2}
\end{aligned}
$$

$$
\begin{aligned}
& \left\{\left(\text { b.x. } \frac{x}{2}\right)+(\text { n.As' })(\mathrm{x}-\mathrm{d})=(\text { n. As })(\mathrm{h}-\mathrm{x})\right\} \\
& \left(150 \cdot \mathrm{x} \cdot \frac{x}{2}\right)+(2.50,24)(\mathrm{x}-10)=(2.50,24)(130-\mathrm{x}) \\
& 75 x^{2}+100,48 x-1004,8=13062,4-100,48 x \\
& 75 x^{2}+200,96 x-14067,2=0 \\
& x^{2}+200,96 x-14067,2=0 \\
& \mathrm{y}_{\mathrm{c}}=\mathrm{x}=12,421 \mathrm{~mm} \\
& \text { Ix }=\frac{1}{12} \mathrm{~b} \mathrm{~h}^{3} \\
& =\frac{1}{12} 150.12,421^{3} \\
& =23954,04 \mathrm{~mm}^{4}
\end{aligned}
$$

Tegangan desak beton,

$$
\begin{aligned}
f^{\prime}{ }_{c} & =\frac{M \cdot y c}{I x} \\
& =\frac{7,175 \cdot 12,421}{23954,04} \\
& =16,900 \mathrm{MPa}
\end{aligned}
$$

Tegagan lentur beton,

$$
\begin{aligned}
\mathrm{fr}= & 0,9 . \mathrm{f}^{\prime} \mathrm{c}^{0,5} \\
& =0,9 \cdot 16,90^{0,5} \\
& =3,700 \mathrm{MPa}
\end{aligned}
$$

Hasil perhitungan tegangan lentur balok semua benda uji dapat dilihat pada Tabel 8 .

Tabel 8. Tegangan Lentur Benda Uji Balok Beton Bertulang

$$
\text { Jenis beton bertulang } \quad \begin{gathered}
\text { Tegangan lentur } \\
\text { beton }(\mathrm{MPa})
\end{gathered}
$$

\begin{tabular}{ll}
\hline Beton Normal & 3,700 \\
Beton Serat 1\% & 3,947 \\
Beton Serat 2\% & 3,877 \\
Beton Serat 3\% & 4,049 \\
Beton Serat 4\% & 4,035 \\
Beton Serat 5\% & 4,021 \\
Beton Serat 6\% & 4,059 \\
\hline
\end{tabular}

Grafik kuat lentur beton ditampilkan pada Gambar 


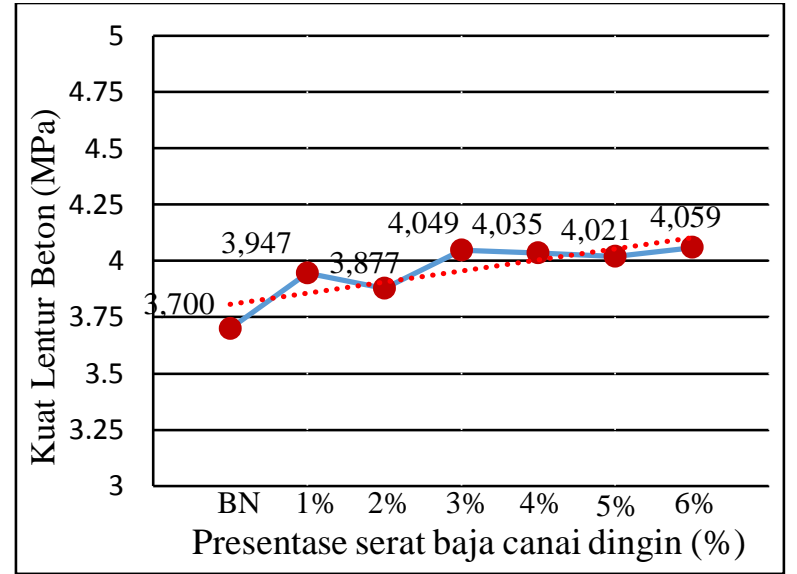

Gambar 18. Kuat lentur beton pada seluruh benda uji

Hasil analisis menunjukkan terjadinya trend kenaikan kuat lentur beton seiring dengan bertambahnya presentase serat baja. Presentase penambahan serat baja optimum yaitu $6 \%$.

Dari hasil uji lentur diperoleh bahwa serat baja canai dingin berbentuk gelombang mampu menambah kemampuan ikat antar partikel beton. Hal tersebut terbukti pada Gambar, serat baja yang ada di dalam balok membantu menahan retakan tidak membesar ketika batas retak beton sudah tercapai.

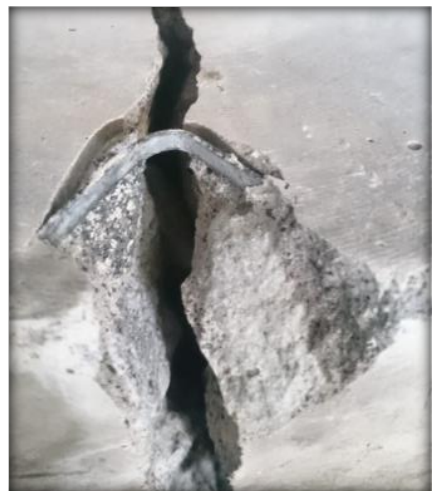

Gambar 19. Serat baja di sela retakan beton

\section{Kesimpulan}

Setelah dilakukan pengujian dan analisis maka ada beberapa kesimpulan diperoleh dari penelitian ini, yaitu :

1. Pengujian benda uji menunjukkan bahwa semakin banyak presentase bahan tambah serat baja canai dingin yang diberikan ke dalam campuran beton justru semakin menurunkan kekuatan tekannya. Bahkan pada tambahan serat yang terlampau banyak yaitu presentase $5 \%$ dan $6 \%$ justru akan membuat kuat tekan beton berada di bawah kuat tekan beton rencana.

2. Pengujian benda uji menunjukkan bahwa semakin banyak presentase bahan tambah serat baja canai dingin yang diberikan ke dalam campuran beton bertulang semakin kuat ketahanannya dalam menahan lentur. Hal tersebut terlihat dari semakin besar momen yang dapat dipikul oleh balok pada saat pengujian.

3. Semakin besar presentase tambahan serat baja canai dingin yang diberikan meningkatkan kuat lentur (flexural strength) beton.

4. Kuat tekan optimum diperoleh dengan penambahan $1 \%$ serat baja canai dingin sedangkan kuat lentur optimum didapat pada penambahan $6 \%$.

\section{Daftar Pustaka}

ACI Comittee 211.1 (2002). Standard Practice for Selecting Proportions for Normal, Heavyweight, and Mass Concrete, Detroit

ACI Comittee 318 (2014). Building Code Requirements for Structural Concrete, American Concrete institute, Farmington Hills

Anonim (1982), Peryaratan Umum Bahan Bangunan di Indonesia (PUBI 1982), Pusat Penelitian dan Pengembangan Pemukiman, Badan Penelitian dan Pengembangan, Departemen Pekerjaan UMUM, Bandung

Badan Standarisasi Nasional, (2011), SNI 1974:2011 Cara Uji Kuat Tekan Beton Dengan Benda Uji Silinder, Jakarta

Badan Standarisasi Nasional, (2014), SNI 4431:2011 Cara Uji Kuat Lentur Beton Normal dengan Dua Titik Pembebanan), Jakarta

Badan Standarisasi Nasional. (2013). SNI 2847:2013 Persyaratan beton struktural untuk bangunan gedung, Bandung

Badan Standarisasi Nasional. (2012). SNI 7656:2012 Tata cara pemilihan campuran untuk beton normal, beton berat dan beton massa, Bandung

Nasution, Amrinsyah (2009), Analisis dam Desain Struktur Beton Bertulang, Penerbit ITB, Bandung

Pawirodikromo, Widodo (2014), Analisis Tegangan Bahan, Cetakan II, Pustaka Pelajar, Yogyakarta

Reni, Iskandar, (2014), Karakteristik Kuat Lentur Beton Ringan Akibat Penambahan Styrofoam Pada Desain Campuran Beton, Universitas Riau, Pekan Baru

Reno, Eko, (2017), Studi Analisa Kuat Tarik Material Baja Ringan Yang Digunakan 
Pada Bangunan Di Kabupaten Garut, Sekolah Tinggi Teknologi Garut, Garut

Tjokodimuljo, Kardiyono (2007), Teknologi Beton, Biro Penerbit KMTS FT UGM, Yogyakarta

T.Y.Lin dan Ned H.Burns (1981), Design of Prestressed Concrete Structures, Berkeley, California dan Austin Texas

Saiful, (2018), Pemanfaatan pecahan genteng, abu batu dan superplasticizer terhadap pengaruh kuat tekan dan lentur beton, Tugas Akhir, Universitas Teknologi Yogyakarta, Yogyakarta

Zafira Atika Ulima, (2017), Studi eksperimental pengujian kuat tekan, kuat tarik belah dan kuat lentur pada campuran beton dengan penambahan serat kawat bendrat berkait, Tugas akhir, Universitas Muhammadiyah Surakarta. Surakarta 